\title{
The Revolution of Facebook: Political Education on Social Media through
} Nonformal Andragogical Communities of Practice

\author{
Donald Moen
}

\section{Introduction}

As social media has become more and more ubiquitous in $21^{\text {st }}$-century society, many have moved into silos in their use of social media. Facebook is one platform which has several member created groups varying a panoply of interests. The history of learning about communism has been a mix of propaganda and education, fraught with controversy. This paper seeks to explore the phenomenon of Facebook groups that advocate for communism, considering them as digital nonformal andragogical educational communities of practice.

\section{| Justification}

Most literature about Facebook in Education and its communities of practice has centered on formal educational environments, like classes, and has not focused on nonformal (outside of the classroom) environments outside of structured education. Keles (2018) has considered the interplay of teachers and students in sharing responsibility for learning within Facebook groups. Wong et al. (2011) explored knowledge building and collaborative learning on Facebook communities of practice through analysis of student messages, and Kenney et al. (2013) analyzed the peer support of doctoral students within their Facebook community to achieve common goals. Whittaker et al. (2014), through the study of undergraduate science students, have concluded that Facebook can be used to create an online educational community benefiting social support, problem-solving, and effective communication. Avram (2014) has examined the use of Facebook groups in the academic communication process within higher education between and amongst teachers and students. Cunha Jr. et al. (2016) have reported that Facebook groups have led to improved communication between students and teachers as well as improving the engagement of students. The field of Education has been documenting formal education when exploring communities of practice on Facebook and has not extensively investigated nonformal education, which is a common locale for the development of andragogy.

Research on group behavior and political expression on Facebook has not focused mainly on education or communities of practice. Liu et al. (2017) have explored Facebook user reticence to 
express political opinions. Ferrara (2012) has shown the reproducibility of community structure on Facebook through algorithmic analysis. Dobrowsky (2012) has researched identity construction through "...spaces of communication, in which individuals can work on their identity in processes of interaction" (p. 91), allowing the sampling of different identities which was previously much more limited in history. Du Preez and Lombard (2014) contend that while memes are part of identity construction, they are also part of identity display as they reveal true impressions of the user's offline persona. Casteltrione (2014) has proposed that Facebook can decrease the risk of political fragmentation and polarization, and elsewhere that members pre-existing levels of political activity reflect their mobilization efforts on Facebook (Casteltrione, 2016). Kearney (2016) connects political engagement on Facebook with interpersonal goals theory concluding that "...political posts entail greater affective and interaction-related risks than following political pages or updating one's profile, while "liking" political posts afford users a low-cost/low-reward strategy for managing interactions" (p. 106). The analysis of political behavior on Facebook has not considered communities of practice, a primary location of andragogic development.

Hence, this paper considers political education in Facebook groups as nonformal andragogic communities of practice, something lacking in the literature. Through the discussion of who these groups are, what they do, how they differ from other groups, and how they have been educated, these communities are shown to be intellectually sophisticated with communal identities whose complexity exists outside state control within a community of practice.

\section{On Andragogy}

Stemming from Knapp's 19th century definition of andragogy as “...methods or techniques used to teach adults..." (Maddalena, 2015, p. 1), andragogy is a term used to differentiate adult learning from pedagogy, the term applying to the learning of children. Knowles (1996) explains that pedagogy is often based on the transfer of knowledge to children. This is unlike adults who are generally self-motivated, having the agency to stop learning as opposed to children mandated to be in schools. Knowles highlights four significant differences between pedagogy and andragogy. First, the learner is self-directed rather than dependant upon the learning environment. Second, there is a "reservoir of experience" (p. 55) that the learner taps into as a learning resource. Third, social roles dictate learning readiness. Fourth, the application of knowledge is much more immediate so the "...orientation toward learning shifts from one of subject-centeredness to one of problem-centeredness" (p. 55).

Elias and Merriam (2005) distinguish formal learning contexts such as schools, from informal learning contexts like professional seminars, and nonformal learning contexts like peerto-peer (P2P) learning. In short, formal learning environments lead to credentials (University education), while informal learning environments do not lead to a credential but use classroom environments and formalized procedures (new employee training/orientation). Nonformal environments do not have formally established procedures; learning occurs incidentally without preparation (asking a colleague for experience). Elias and Merriam found that most adult learning occurs non-formally, outside of formal and informal classrooms, so P2P learning on social media occurs non-formally like most adult learning, without a formalized curriculum. Through the P2P process, the cohesion and identity of a group is reinforced, and the sense of ownership of the learning offered is cemented.

\section{Community of Practice}

Facebook groups can be more impactful than many classrooms for political education because they provide a community of practice. Not only do these groups furnish community membership, but also periphery membership. Many members evolve into communities rather than jump into 
them. Hoadley (2012) argues access to experts, common identity, and peripheral participation are the key elements of a community of practice. First, experts need to be available for new members to learn from and pose questions to. It is necessary for new participants to possess the desire to enter the process necessary to become experts. Second, in order for a new participant to join the common identity of the community of practice, the aforementioned identity must already exist. These groups certainly have a common identity as communists. Third, participation in the community of practice usually starts on the margins of the community and individuals slowly move towards the center. Hoadley argues that participants "...need to have a space in which it is legitimate to be on the periphery..." (p. 291). Rather than taking a class in a college or university or purchasing a book, members of a Facebook group can dip their proverbial toes in the water, which allows the educational process to take the time the individual needs to approach discovery in learning, and also sample different identities (Dobrowsky, 2012; Du Preez \& Lombard, 2014).

The C4P framework (Figure 1) outlines a systematic way in which communist Facebook groups create a community of practice. Through content, conversations, connections, and context, the purpose is established within the community of practice (Hoadley \& Kilner, 2005). This model provides the necessary flexibility that a diverse community requires as it facilitates peripheral membership and allows new members to evolve into the community (Hoadley, 2012). Liu et al. (2017) have connected the Spiral of Silence framework to the expression of political opinion on Facebook; periphery membership can allow a group member to ease out of one's reservations and the anonymity of the group, where posts are not publically accessible and can overcome the reticence to express political views. Additionally, amongst diverse educators, Hoadley and Kilner explain the C4P framework conforms to various relational philosophies of education such as behaviorist, developmental, cognitive, and sociocultural learning while rejecting neoliberal models of knowledge transmission. This overcomes barriers to different styles of learning which can be difficult to conquer in formal and informal classroom contexts.

\section{C4P Framework for Communities of Practice}

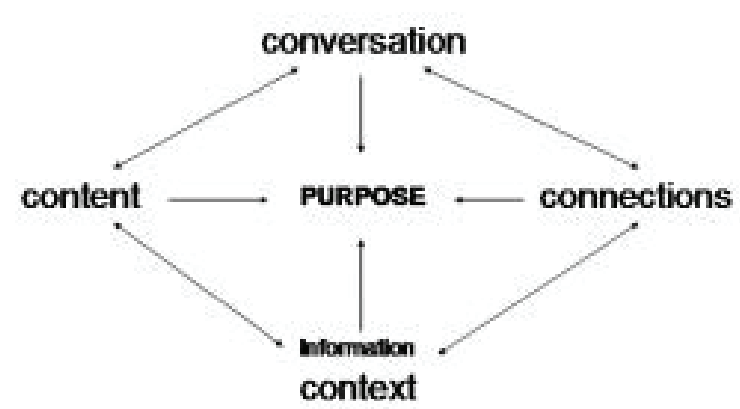

Figure 1. C4P Framework (Hoadley \& Kilner, 2005, p. 34)

Hoadley and Kilner (2005) contend that content is attractive to new members of a community of practice because it provides immediate value and implicit socialization. Hoadley (2012) adds that content provides immediate periphery membership through non-committal action, such as articles and guides easily accessible to members on the periphery through the social networking system. The sharing of articles is a primary focus of these Facebook groups. 
Hoadley and Kilner (2005) argue that conversation focusing on content builds knowledge, especially in the context of a shared purpose and objective. These conversations establish a culture of safety within the community of practice and allow members to talk through ideas they might not otherwise present. Quality content and conversations build connections which Hoadley and Kilner call "...the lifeblood of a knowledge community" (p. 34). This highlights the deep theoretical and historical discussions within these groups as quality content.

\section{| Digital Ethnography}

A digital ethnography approach was used for data collection. The researcher embedded himself into several groups on Facebook and developed community membership in these groups. Garcia et al. (2009) describe digital ethnography:

Observation in online research involves watching text and images on a computer screen rather than watching people in offline settings. However, the technologically mediated environment still provides direct contact with the social world the ethnographer is studying, since participants in that setting communicate through online behavior. (p. 58)

Talip et al. (2017) contend that "nuanced aspects of use" (p. 92) can be gleaned through this inductive method, which allows the researcher to better understand the phenomenon.

Facebook was chosen because of its prevalence of groups, particularly those with a radical Left ideology. Unlike a platform like Twitter, which is more open, closed groups can allow for more radical discussion due to their perceived privacy (Talip et al., 2017, p. 58). Participants' accounts were surveyed to see their professional, geographic, and educational backgrounds.

Due to the sensitive information potentially shared and the potential risk to participants, anonymization was central; therefore, no specific examples have been included from participants as they could potentially be traced back. Rather than simply adhering to an ethics approval and traditional macroethical guidelines, microethical considerations about the "... differences in the perceptions, expectations, values, and goals of all parties must be constantly negotiated in a responsive and contextually-sensitive process" (Tagg et al., 2017, p. 273). Naturally, it would have been more advantageous to the researcher to include more specificity, but ethics did not permit this. While some might consider these ethical measures extreme, Neo-McCarthyism is a real phenomenon (de Pracontal, 2017). No Facebook comment can be anonymized from potential government overreach (Lovett, 2018). Therefore, strict anonymization was the most ethical way to protect participants.

\section{Digital Andragogical Nonformal Educational Communities of Practice}

In a digital andragogical nonformal educational community of practice there is a meeting place online comprising of self-motivated adults without any specific learning outcomes as dictated by curriculum in which the participants engage in identity construction around a learning topic. These are online spaces, intended for adults, which do not offer certification, and have highly motivated and curious participants. Members can not only participate at the fringes in the beginning and develop both into a greater knowledge of the subject, but also slowly develop a group identity. They tend to follow Hoadley and Kilner's (2005) C4P model of content, conversations, connections, and context.

In the case of Communist Facebook groups, members are comprised of adults. There are not formal curricular items. Learning is not planned in a curricular sense. Members often start with periphery participation and grow into group membership. This often results in members adopting and expressing a new political identity as communists learning through content, conversations, 
connections, and context.

\section{Scope of Investigation}

While communism and socialism have often been used interchangeably in History, this paper seeks to consider those who directly identify themselves as communists. To a traditional Marxist definition, socialism has been defined as the conditions and political governance leading to communism, which is an ideal that has never been achieved; this is why states usually have included the word 'socialism,' rather than the word 'communism,' in their names. Communism has been an aspirational goal. However, the term 'socialism' has been used in the discussion of social democracy in Europe, and more recently, democratic socialism in the United States with Bernie Sanders. Communism has a much more closed and radical connotation, and this paper seeks to consider its discussion on social media.

It is essential to note this is a paper considering Education, and is not a work of History or Political Science. While many events in the history of communism can be criticized, the scope of this paper is not to engage these debates; rather, the objective is to bespeak that these considerations are occurring on social media. It is not the goal on this paper to take a liberal view against Marxist-Leninism, nor is it the goal to take a Marxist-Leninist view against liberalism.

It bears repeating that it is necessary to clarify some limitations stemming from ethical boundaries. Specific examples of group members' writings have not been included as their anonymity could not be guaranteed. Images associated with these groups have been found on secondary websites and cited as such. The exact names of groups, participants (including their pseudonyms), and the sources of imagery have been anonymized for their own personal protection. This produces the limitation that the exact quotation of group members is not presented for evidentiary purposes. Therefore, this study tries to present the proverbial broad-strokes while maintaining the anonymity of those who could be targeted for their beliefs.

\section{Who Are They?}

Members of Communist groups span the world and so do their sources. Members from South and North America, all parts of Europe, Russia, the Middle East, Africa, India, Australia, and East Asia can be found sharing local and global resources.

Communist Facebook groups are explicit in their support for communism. Their names often include the word "communism" or have a central communist figure in the name like Lenin, Stalin, Mao, Marx, Xi, Deng, etc. They also include different functions like discussion, advocacy, dating, memes, anime, national association, religion, atheism, and other interests. These are all characteristics of Hoadley's (2005) C4P Framework of identity construction through education, tapping into the "reservoir of experience" (p. 55) described by Knowles (1996).

The primary age group is the millennial generation. Media outlets have reported a preference for socialism or communism amongst the millennial generation (Market Watch, 2017; Washington Times, 2017), and Kearney (2016) has documented young adults' penchant for preferring political activity and education on Facebook. Corbet and Gurdgiev (2017) have also made known millennials sinking support for liberal democracy and its institutions. They argue that this is not due to political or electoral outcomes from interference by states like Russia or China; rather, millennials dwindling faith in liberal democracy seeds from the socio-economic imbalance their generation is experiencing vis-à-vis older generations.

Communist groups tend to understand the differences between different types of socialism. Many members are Marxist-Leninist in leaning, but social democrats and Trotskyites also participate. Social democrat and Trotskyite groups also exist. There is a strong debate about the nuanced differences between socialist ideologies, which is not limited to general leanings, but 
often supported with primary source writings by major socialist thinkers. The works of Mao, Stalin, Lenin, Trotsky, Marx, Gramsci, Engels, Hoxha, and others are often quoted. Even the nuance between Marxist-Leninism and Marxist-Leninism-Maoism are often seen as common knowledge in these communities.

\section{| What Do They Do?}

The communist groups participate in sharing various types of information. Support for North Korea and Venezuela often through memes, news articles about communism and antiimperialism, criticism of different political philosophies including other types of socialism, polls on political leanings, Marxist cartoons, religious debates, and humourous subjects often involving anti-colonial, anti-corporate, anti-capitalist, and pro-Marxist memes.

Communist groups are often authoritarian. In their community standards they often explicitly state members will be banned for liberal and conservative views, unless they are present to learn about communism. Authoritarian communist expressions are also incorporated. Members are not banned but purged. They are not suspended but sent to the Gulag. While in a liberal democracy, terms like 'purge' and 'Gulag' are often reviled, in these communities, they are often revered. These terms express the social-economic justice pined for by millennials that Corbet and Gurdgiev (2017) have elucidated. Stalin's purges are often regarded as criminal justice, and the Gulag providing protection from criminal elements in society.

Clarifying the history of communist states is also a mission of communist Facebook groups. There are several posts about how many deaths for which Stalin and Mao ought to be responsible. There are questions about the veracity of the claim that famine in the Ukrainian genocide or Great Leap Forward were willfully enacted by communist leaders. Not only do they seek to refute claims of tens of millions killed by communism as purported in the Black Book of Communism (Courtois, 2005), members are aware of the claims by Solzhenitsyn of mass murder under communism, and even refute him through his own work (Solzhenitsyn, 2008). Timothy Snyder's Bloodlands (2010), which has much smaller political death counts in the Soviet Union but still in the millions, is criticized as liberal propaganda, much as it has been in socialist circles (Lazare, 2017). Groups also include criticism of larger claims under the Great Leap Forward (Babiarz et al., 2015). The death rate and history behind the so-called Iron Curtain is a debated point within the academy; it is not the mission of this paper to enter into this debate. Rather, communist Facebook groups are aware of the nuances of academic debate on the issue and seek to popularize a pro-communist reading of history.

Communist Facebook groups actively try to defend communism and attack its opponents. Members will participate in praxis by raiding the comments sections of anti-communist posts, some even joining groups opposing communism to agitate and educate. Propaganda against communism will often be posted and then deconstructed and argued against. Often memes against communism are edited into pro-communist propaganda.

These groups do not have formal curricula but engage in content, conversations, connections, and context (C4P). They use primary source materials, build community, and develop context about the history of communism compared with the liberal-democratic philosophy, which dominates politics today. They challenge the legitimacy of liberal-democrat ideology as a natural context, arguing for a context that does not reform liberal-democracy but replaces it. Not only is this a central tenant of Lenin's own writings, members directly quote these tenets from seminal works like State and Revolution or What Is To Be Done? As digital nonformal andragogic educational communities of practice, these are online groups of adults without a curriculum developing a political identity and being educated in a political philosophy through content, conversations, connections, and context. 


\section{| How Are They Different from Other Facebook Groups?}

There is a sharp contrast between the comments in these Facebook groups and the comments on political news stories. When analyzing the comments of a political article on Facebook, comments are generally filled with personal opinion and anecdote, lacking depth and often trailing off-topic (Hille \& Bakker, 2014). These comments rarely cite political theory, historical context or referenced material. What separates communist Facebook groups is that, while expressing opinion and anecdote, they also provide political theory, historical context, and referenced material on many occasions. The discourse more resembles a university-level discussion group than a water cooler political conversation.

This stands in stark difference to other political groups such as 'woke' liberal Facebook groups. These groups are mostly filled with articles from the mainstream press, critical of conservative figures like Boris Johnson or Donald Trump. They lack almost any references of political science studied in the Academy. Some have included posts about academics like Jordan Peterson, but they are limited to memes about cleaning one's room, a reference to his popular self-help book 12 Rules for Life (Peterson, 2018). However, there are no references to his peer reviewed work, or Maps of Meaning (Peterson, 1999). The genre seems limited to nonfiction and non-academic referenced material. Furthermore, there are not woke liberal groups citing seminal philosophical works in the history of liberalism like Rousseau's Du contrat social; ou Principes du droit politique or discussion of the Hobbes and Locke debate on human nature from participants without higher education. However, in communist Facebook groups, original works by Marx, Engels, and Lenin are often discussed and cited by those who lack higher education on their profiles. Woke liberal groups do not discuss economic differences between Keynes and Friedman, like a discussion between Dengist and Maoist economics. In short, these liberal groups are not digital nonformal andragogic educational communities of practice. They meet having an existing political identity; while sharing mainstream press news articles can be informative, it is not education with material also used in university education, building identity and complex knowledge through content, conversations, connections, and context.

Community identity and level of academic debate separate communist Facebook groups from other communities on Facebook. There are several philosophy groups on Facebook which have a high level of academic discussion. Profile analysis often reveals a formal education in the Humanities, and commonly Philosophy itself as a university major in these philosophy groups. While the debate is sophisticated, there does not seem to be the same community membership or identity construction to being 'a philosopher' that being 'a communist' constructs. Kearney (2016) has argued that political participation on Facebook has more connection to interpersonal goals than most other behaviors. Simply put, arguing the tenets of Marxist-Leninism is often more connected to identity than debating Kant's rationalism versus Hegel's dialectic. Conversely, right-wing Facebook groups have a strong attachment to identity, but the cultivation of academic debate in pro-Trump, New Right, Alt-Right, Neo-fascist, etc. circles can be lacking. Authoritarian Populism has never been much for quoting the academy (Hall, 1988).

\section{How Have They Been Educated?}

When personal profiles are analyzed, most individual group members do not have academic backgrounds in relation to fields like history or political science. Although some group members have higher education, it is varied amongst several fields, and many do not have higher education. Simply put, these are not groups of history and political science majors bantering about their university studies. Many of these members are employed in service professions like cooking and serving, or they are unemployed. There are certified professionals in their ranks as well.

It appears that group members have obtained political and historical knowledge in a nonformal tting. Elias and Merriam (2005) distinguish formal learning contexts such as schools, 
from informal learning contexts like professional seminars and from nonformal learning contexts like peer-to-peer learning. They found that most workplace learning occurs non-formally, outside of formal and informal classrooms. This would suggest Facebook groups can work similarly to workplace education or so-called 'on the job training.' Keles (2018) has connected the Community of Inquiry framework to teaching presence in Facebook groups. He found that “... FB's [Facebook's] social network supported a teaching presence for both the instructors and the students and enabled them to share responsibility for the teaching process" (p. 203). Communist Facebook groups are working through a symbiotic and syncretic knowledge dissemination network which allows members to be both teacher and student inside of the community of practice. With so many genres of communist orientation being debated, those on the periphery are free to experiment and taste the menu of Maoist, Trotskyist, Stalinist, Hoxhaist, Dengist, etc. ideology and syncretically form their own unique belief systems in much the same modern spirituality will take from several religions.

The groups use memes to educate both simple and complex Marxist principles. For example, Figure 2 shows a straightforward graphic displaying Marx's argument of wage theft. It then juxtaposes wage theft against capitalist or libertarian logic towards surplus value. There are also complex analyses of Marxist history and theory, especially posts of videos by the YouTube contributor The Finnish Bolshevik (2015), one such video detailing issues with the controversial testament of Lenin, which renounced Stalin. There is the reading of scholarship about Stalin from researchers like Kotkin (2014) and Zižek (2017), and social media presentations of criticism of their work (The Finnish Bolshevik, 2016). Again, there is a divided scholarship on these issues (David-Fox, 2016), but the point is that communist Facebook groups are educational spaces that explain both simple and complex political ideas. There is a conversation about this content, which is contextualized by its supporters' building connections in the community, which then brings those in periphery participation closer to the center of the ideology - the C4P framework.

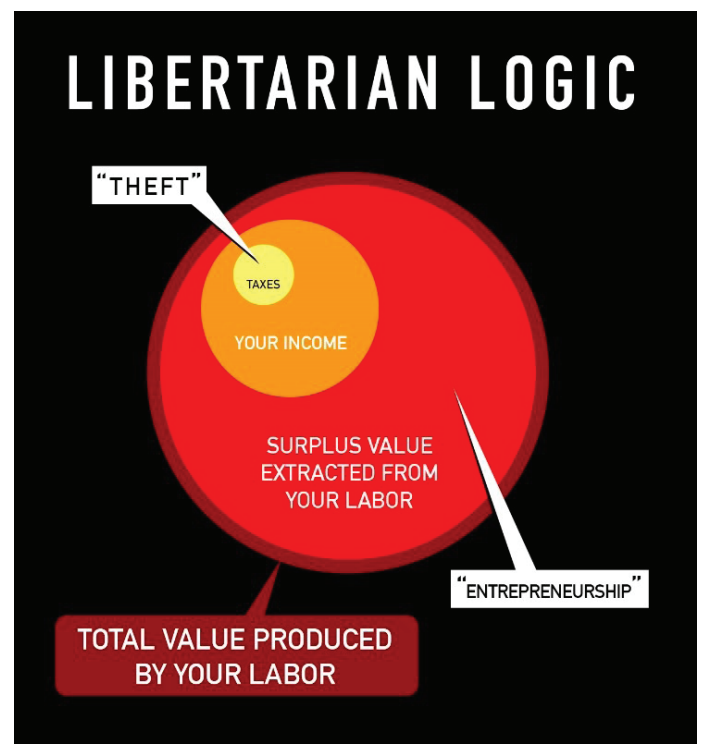

Figure 2. Libertarian Logic (Bemky, n.d.)

\section{The Political Compass}

The political compass is a tool used in political science to map political belief in four quadrants. The traditional left wing to right wing analysis is placed on the $\mathrm{x}$-axis, while authoritarianism is juxtaposed with libertarianism. These four orientations create a map in which 
one can parse the differences between the authoritarian Left and Right, and the libertarian Left and Right (Figure 3). The purpose is to provide two dimensions to the traditional one dimension of Left versus Right analysis, but it is still only two-dimensional and other political science models provide much deeper analysis. The political compass is not without criticism in academic circles (Cole, 1995), but it is a noticeable development that an academic quadrant political plotting tool appears within a social media group.

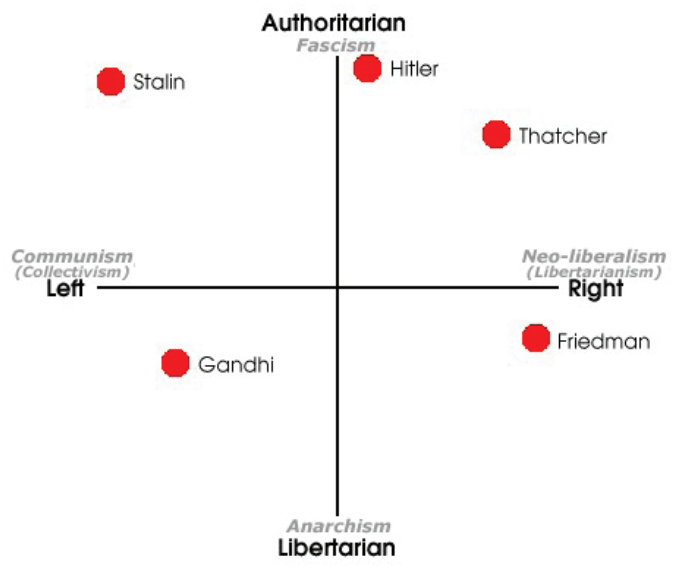

Figure 3. Political Compass (Political compass team, 2017)

The political compass is used seriously and humorously. Popular culture references, like referencing Game of Thrones (Figure 4), is a common theme in its use. Some members will post a variety of historical figures and then debate over where they actually belong; Figure 4 is an example of this, which included long debate over various figures. Figure 5 is not presented as an empirical historical example of where these characters would really lie on the political compass; rather, it is an example of how debate and education through the political compass and memes using the political compass is present in these communist Facebook groups. The appearance of this depth of political analysis, and play with this analysis, is a part of the C4P model. Liberal groups could be displaying this level of analysis, but are instead sharing press articles. Conservative groups are much the same. Communist Facebook groups develop a general higher level of political education for adults. 


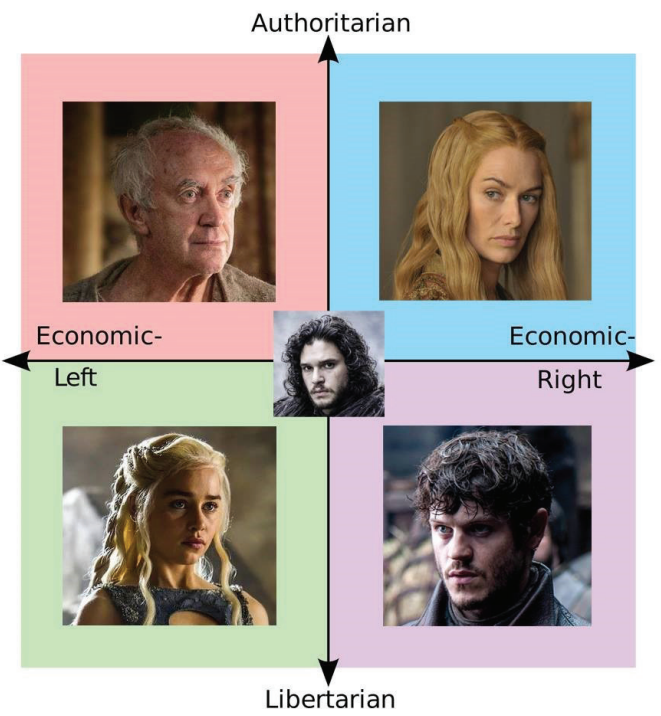

Figure 4. Game of Thrones Political Compass (Party9999999, n.d.)

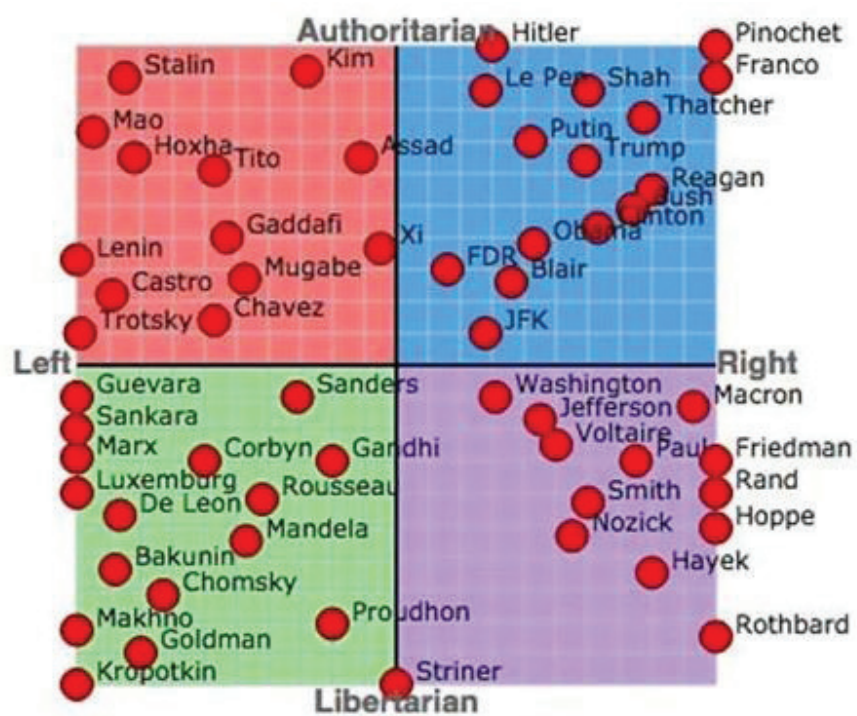

Figure 5. Historical Characters on the Political Compass (Tee, 2017)

\section{Outside of State Control}

The state has historically had control of political education through the educational system and the media to a large degree. Bourdieu (1984) has argued that control over the educational system equates to control of the state. States have had to approve curricula and media outlets have historically had to exist within the basic confines of popular taste, often confined by the curriculum presented by the state, allowing vigorous debate, but within well-defined ideological boundaries (Herman \& Chomsky, 2002). Political education through social media changes this norm. Market forces are not required as hosting a political group on Facebook has no cost, while historically printing newspapers, starting television channels, and hiring journalists has been 
an expensive proposition. Additionally, Dobrowsky (2012) has revealed how identities can be sampled on Facebook in a way that has not previously existed in human history by taking the power of identity construction away from traditional institutions of school, family, and other associations, which allows individuals to shape their own identities. In communist Facebook groups, this appears to be occurring through the C4P framework.

Groups on Facebook allow users to sidestep algorithms. Brake (2017) has shown the influence algorithms have on affecting what journalistic reports appear in social media, including Facebook. In the United States, National Public Radio has reported that Facebook has adapted its algorithm to favor groups in Facebook timelines (Shahini, 2017). Being in a Facebook group makes it more likely to receive information from the group than simply 'liking' a page on Facebook which means group members are more likely to get a news story or other link in their newsfeed from another group member than from standard journalistic news websites. While these members are divided into a variety of groups, Ferrara (2012) reports that on Facebook, "...people tend to aggregate principally in a large number of small communities instead of in very large communities" (p. 13), but despite this, the structure of communities stays the same amongst groups, and this structure can even be detected quantifiably.

\section{Conclusion}

In a broad fashion, Facebook groups can be seen as communities of practice when providing knowledge dissemination and community membership. It is important to differentiate that some knowledge dissemination does not provide identity-defining community membership and some community membership does not provide a substantial-quality of knowledge dissemination. Communist Facebook groups are one such environ in which identity-defining community membership, practice through such a community, and substantial quality of knowledge are combined in a non-formal context.

Researchers ought to consider in greater detail communities of practice working on social media in the nonformal context. While formal and informal contexts continue to be important, most adult learning occurs non-formally. Therefore, if academia wishes to understand the development of political education in the 21st century, or the progression of any learning in any field, the functioning of non-formal andragogical communities of practice on social media is essential to understanding the field of Education in its modern context. 


\section{References}

Avram, E. M. (2014). Facebook Communication in Higher Education. SEA-Practical Application of Science, 2(3), 5.

Babiarz, K. S., Eggleston, K., Miller, G., \& Zhang, Q. (2015). An exploration of China's mortality decline under Mao: A provincial analysis, 1950-80. Population Studies, 69(1), 39-56. http://doi.org/10.1080/003247 28.2014.972432

Bemky. (n.d.). The Average Libertarian's Logic Retrieved from https://steemit.com/news/@bemky/ the-average-libertarian-s-logic

Bourdieu, P. (1984). Distinction: A social critique of the judgment of taste. (R. Nice Trans.). Cambridge, Mass.: Harvard University Press. (Original work published 1979)

Brake, D.R. (2017). The invisible hand of the unaccountable algorithm: How Google, Facebook and other tech companies are changing journalism. In: Tong J., Lo SH. (eds) Digital Technology and Journalism. London, UK: Palgrave Macmillan.

Casteltrione, I. (2014). Facebook and Political Information in Italy and the UK: An Antidote against Political Fragmentation and Polarisation?. Online Journal of Communication and Media Technologies, 4(1), 27.

Casteltrione, I. (2016). Facebook and political participation: Virtuous circle and participation intermediaries. Interactions: Studies in Communication \& Culture, 7(2), 177-196.

Cole, P. (1995). Finding one's way around the political compass (or why libertarianism is right-wing). Journal of Social and Evolutionary Systems 18(3), 207-211.

Corbet, S., \& Gurdgiev, C. (2017). Millennials' support for liberal democracy is failing: A deep uncertainty perspective. Retrieved from: https://www. scribd.com/document/362536900/Millennials -and-Liberal-Democracy-2017-08

Courtois, S. (2005). The Black Book of Communism: Crimes, Terror, Repression. Cambridge, MA: Harvard University Press.
Cunha Jr, F. R. D., van Kruistum, C., \& van Oers, B. (2016). Teachers and Facebook: using online groups to improve students' communication and engagement in education. Communication Teacher, 30(4), 228-241.

David-Fox, M. (2016). The leader and the system. Kritika: Explorations in Russian and Eurasian History, 17(1), 119-129.

de Pracontal, M. (2017). American Nightmare. Contemporary French and Francophone Studies, 21(5), $567-573$

Dobrowsky, D. (2012). Constructing identity on social networks. An analysis of competences of communication constituted on Facebook.com. Central European Journal of Communication, 5(1 (8)), 91-103.

Du Preez, A., \& Lombard, E. (2014). The role of memes in the construction of Facebook personae. Communication, 40(3), 253-270.

Elias, J., \& Merriam, S. (2005). Philosophical foundations of adult education ( 3 rd ed.). Malabar, Florida: Krieger Publishing Company.

Ferrara, E. (2012). Community structure discovery in facebook. International Journal of Social Network Mining, 1(1), 67-90.

Garcia, A. C., Standlee, A. I., Bechkoff, J., \& Cui, Y. (2009). Ethnographic approaches to the internet and computer-mediated communication. Journal of contemporary ethnography, 38(1), 52-84.

Hall, S. (1988). The hard road to renewal: Thatcherism and the crisis of the left. New York: Verso.

Herman, E. S., \& Chomsky, N. (2002). Manufacturing consent: The political economy of the mass media. New York, NY: Pantheon Books.

Hoadley, C. (2012). What is a community of practice and how can we support it? In S. Land \& D. Jonassen (Eds.), Theoretical foundations of learning environments (pp. 287-300). London, U.K.: Routledge. 
Hoadley, C. M., \& Kilner, P. G. (2005). Using technology to transform communities of practice into knowledge-building communities. ACM SIGGroup Bulletin, 25(1), 31-40.

Hille, S., \& Bakker, P. (2014). Engaging the social news user: comments on news sites and Facebook. Journalism Practice, 8(5), 563-572.

Kearney, M. W. (2017). Interpersonal Goals and Political Uses of Facebook. Communication Research Reports, 34(2), 106-114.

Keles, E. (2018). Use of Facebook for the Community Services Practices course: Community of inquiry as a theoretical framework. Computers \& Education, 116, 203-224.

Kenney, J., Kumar, S., \& Hart, M. (2013). More than a social network: Facebook as a catalyst for an online educational community of practice. International Journal of Social Media and Interactive Learning Environments, $1(4), 355-369$.

Knowles, M. (1996). Andragogy: An emerging technology for adult learning. London, UK.

Kotkin, S. (2014). Stalin: Paradoxes of Power, 1878-1928. New York, NY: Penguin. Lazare, D. (2017). Timothy Snyder's lies. Jacobin. Retrieved from: https://www.jacobinmag.com/2014/09/timothy-snyders-lies/

Lazare, D. (2017). Timothy Snyder's lies. Jacobin. Retrieved from: https://www.jacobinmag. com/2014/09/timothy-snyders-lies/

Liu, Y., Rui, J. R., \& Cui, X. (2017). Are people willing to share their political opinions on Facebook? Exploring roles of self-presentational concern in spiral of silence. Computers in Human Behavior, 76, 294-302.

Lovett, C. C. (2018). McCarthy, David Shaumus. Selling the CIA: public relations and the culture of secrecy. CHOICE: Current Reviews for Academic Libraries, 56(3), 396.

Maddalena, L. (2015). What the \#!\$\% is andragogy? (Pedagogy for Grownups). Manddalena Transition Management. Retrieved from: https://www.researchgate.net/profile/Lucille_Maddalena2/publicat ion/279925413_What_the_is_Andragogy/links/559e738408aeab53f8fd2cc5/What-the-is-Andragogy.pdf
Market Watch. (2017, November 2). Millennials: Communism sounds pretty chill. Retrieved from: https://www.marketwatch.com/story/millennials-communism-sounds-pretty-chill-2017-11-01

Party9999999 (n.d.). Game of Thrones political compass. Retrieved from https://party9999999.deviantart.com/ art/Game-of-Thrones-Politcal-Compass-686090281

Peterson, J. B. (1999). Maps of meaning: The architecture of belief. Psychology Press.

Peterson, J. B. (2018). 12 rules for life: An antidote to chaos. Random House Canada.

Political compass team. (2017). About the political compass. Retrieved from: https://www.politicalcompass.org/analysis2

Shahani, A. (2017, June 22). Facebook changes its mission with announcement about groups. National Public Radio. Retrieved from: https://www.npr.org/sections/ allechconsidered/2017/06/22/534018001/facebookchanges-its-mission-with-groups-announcement

Solzhenitsyn, A. (2008). The Ukrainian famine was not a genocide. Retrieved from: https://www. theglobeandmail.com/opinion/the-ukrainian -famine-was-not-a-genocide/article720047/

Synder, T. (2010). Bloodlands: Europe between Hitler and Stalin. New York, NY: Basic Books.

Tagg, C., Lyons, A., Hu, R., \& Rock, F. (2017). The ethics of digital ethnography in a team project. Applied Linguistics Review, 8(2-3), 271-292.

Talip, B. A., Narayan, B., Edwards, S. L., \& Watson, J. (2017). Digital ethnography as a way to explore information grounds on Twitter. Qualitative and Quantitative Methods in Libraries, 5(1), 89-105.

Tee, C. (2017, November 16). Walang \#duterte \#makungkot the awawzzz \#magandangaraw. Retrieved from https://www.pintaram.com/u/stockbox/164949 9554028242554_191056976

The Finnish Bolshevik (2015, March 21). Lenin's “Testament" debunked. Retrieved from: https://www. youtube.com/watch? $=$ MP8-DID 4b-w\&feature $=$ youtu.be 
The Finnish Bolshevik. (2016, February 11). Zizek \& Kotkin on Stalin. Retrieved from https://www.youtube. $\mathrm{com} /$ watch?v=M3-eFOOE-ss

Washington Times. (2017, November 4). Millennials would rather live in socialist or communist nation than under capitalism: Poll. Retrieved from: https:// www.washingtontimes.com/news/2017/nov/4/ majority-millennials-want-live-socialist-fascist-o/

Whittaker, A. L., Howarth, G. S., \& Lymn, K. A. (2014). Evaluation of Facebook $\odot$ to create an online learning community in an undergraduate animal science class. Educational Media International, 51(2), 135-145.

Wong, K., Kwan, R., \& Leung, K. (2011). An exploration of using Facebook to build a virtual community of practice. Hybrid Learning, 316-324.

Žižek, S. (2017). In defense of lost causes. London, UK: Verso. 